\title{
Environmental lonizing Radiation Survey of Quarry Sites in Ilorin Industrial Area, Nigeria
}

\author{
*L.I. Nwankwo, C.O. Akoshile, A.B. Alabi, 0.0. Ojo and T. A. Ayodele \\ Department of Physics, University of llorin, Ilorin 240003, Nigeria \\ [ Corresponding Author: levinwankwo@yahoo.com; linwankwo@unilorin.edu.ng; R: +2348034044244]
}

\begin{abstract}
An environmental ionizing radiation survey around quarry sites in llorin was carried out using three Radalert Nuclear Radiation Monitors and Global Positioning System (GPS) in order to assess and provide up to date information on radiation levels in the environment. Measured mean radiation levels ranged from $1.11 \pm 0.05$ to $1.72 \pm 0.03 \mathrm{mSv} / \mathrm{yr}$ with an average of $1.49 \pm 0.04 \mathrm{mSv} / \mathrm{yr}$ in the study area. The radiation levels have surpassed the standard level of $1 \mathrm{mSv} / \mathrm{yr}$ by $50 \%$, but fall below the global average of $2.4 \mathrm{mSv} / \mathrm{yr}$ for the general public and 20 $\mathrm{mSv} / \mathrm{yr}$ for occupational environment.
\end{abstract}

Keywords: Radiation, Environment, Industry, Health, Nigeria

\section{INTRODUCTION}

The city of llorin $\left(8^{\circ} 30^{\prime} \mathrm{N} 4^{\circ} 33^{\prime} \mathrm{E}\right)$ is among the top ten largest cities in Nigeria with a population of about 850,000 (Figure 1). Due to its significant peaceful atmosphere and strategic location as the gateway between the northern and southern regions of Nigeria, the city is emerging as an industrial hub in the northcentral region of Nigeria. Industrial activities have been acknowledged as the basis of modern development due to their important contribution to the economic growth and wellbeing of human race, and the benchmark for political and economic classification of towns and nations (FEPA, 1991). Consequently, an industrial district within the city was earmarked by the State Government with various incentives to attract local and international industrialists and investors. These incentives have attracted a large number of industries whose domains of operation are mostly manufacturing, quarrying, chemicals production, bottling, pharmaceuticals, and auto-workshops. Following the upsurge in industrial activities in the area; economic, social and cultural developments have likewise tremendously blossomed.

Nevertheless, industrialization, like other human activities that impact on the environment, often results in pollution and degradation. It carries inevitable costs and problems in terms of pollution of the air, water resources and general degradation of the natural environment (Suflita et al., 1983; Thomas et al., 1992; Adekunle and Eniola, 2008). It is therefore important that the environmental quality of the area be maintained in a good state to ensure a high level of social performance, which can be achieved by close monitoring of pollution factors in the area (Avwiri et al.,
2007; 2009). Specifically, it may not be unlikely to assume that some activities in the area could involve the use of radioactive sources and radiation generators. The presence of these radioactive materials makes it mandatory to monitor and control occupational and public exposures to ionizing radiation. Radiation monitoring is a measure to protect people and environment against the health risks generated by the use and exposure to ionizing radiation. This is aimed at preventing deterministic effects and reducing stochastic effects of biological effects of radiation to an acceptable level.

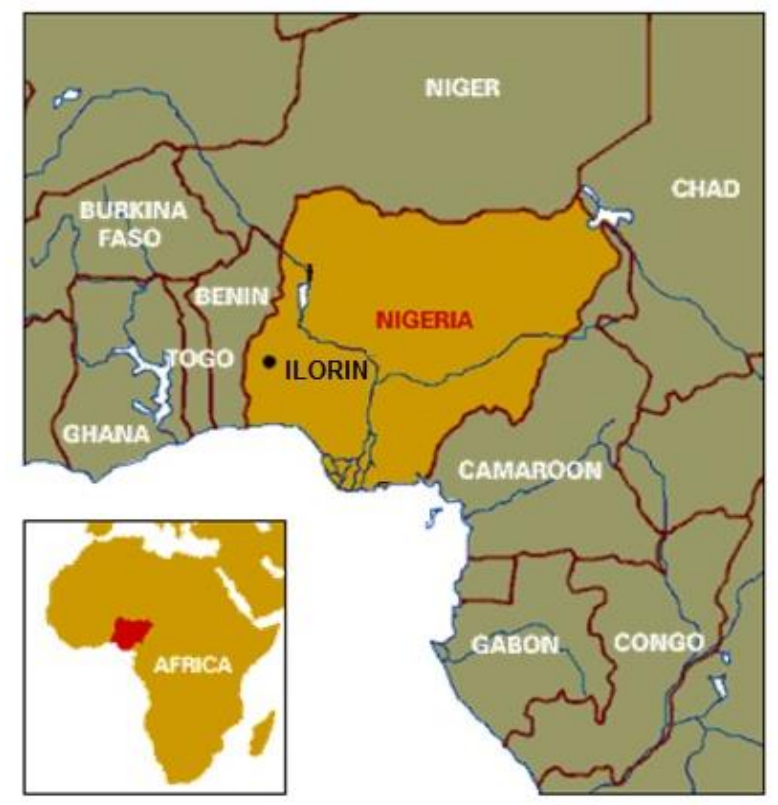

Figure 1: Map of Nigeria showing the city of llorin. 
The environmental impacts of radiations depend on the type and amount of a particular radiation (Gbadebo et al., 2011). However, all forms of radiation constitute danger to biological tissues. The amount of damage of ionizing radiation to biological tissue is $\alpha>\gamma>\beta$. The health effects varies with level of exposure, at an exposure of 70 rem it can results in vomiting and hair loss at the exposure of 100 rem it leads to hemorrhage while exposure rate of between $400-2000$ rem will result in death. This is so because the normal exposure to ionizing radiation is less or equal to $1 \mathrm{mSv} / \mathrm{yr}$. Besides, human exposure to radiations may increase if they live in areas with radiation doses above normal background value.

Hence, this study involves the determination of background ionizing radiation levels around quarry sites in the industrial area of llorin with a view to assessing whether the radiation level is within tolerable limit.

\section{MATERIALS AND METHODS Field Measurements}

The study area falls within unorganized quarry sites located around Asa-Dam area of llorin Industrial layout. In-situ measurements of the background radiation level were carried out using three portable Nuclear Radiation Monitors (Radalert 100) and Global Positioning System (GPS). The measurements were taken simultaneously using the two monitors at every 20 minutes interval for 10 successive readings per station. Following standard procedure, the window of the radiation meter was held at a distance of $1.0 \mathrm{~m}$ above the ground level (Kurnaz et al., 2011). Eighteen measurement points were strategically selected in the study $r$ adequate coverage of the quarrying activities in the area. The precise location of the measurement points are shown in Table 1. The area is on a relatively high elevation with altitudinal values in the range of 280 to $310 \mathrm{~m}$ above sea level.

\section{RESULTS AND DISCUSSION}

The results obtained from the measurements represent the external background radiation level of the studied area. The readings and the average from the three monitors for each measurement location are shown in Table 2. The measured radiation levels for the study locations ranges from $1.11 \pm 0.15 \mathrm{mSv} / \mathrm{yr}$ to $1.72 \pm 0.33$ $\mathrm{mSv} / \mathrm{yr}$ with an average of $1.49 \pm 0.14 \mathrm{mSv} / \mathrm{yr}$. Unlike stations 12 and 16 which have the radiation profiles below $1.2 \mathrm{mSv} / \mathrm{yr}$, stations 6 and 7 have the highest radiation profile of $1.72 \mathrm{mSv} / \mathrm{yr}$. The high profile recorded in these stations could be ascribed to the concentration of quarrying activities in the section, which extends to station 1. Earlier study carried out within a fraction of the present area showed that the average radiation level was equivalent to $1.2 \mathrm{mSv} / \mathrm{yr}$ (Nwankwo and Akoshile, 2005). This indicates an increase in radiation level of the study area, which could ordinarily be attributed to the recent upsurge in industrial activities witnessed in the industrial area.

According to international recommendations, occupational exposure to radiation should not exceed $20 \mathrm{mSv} / \mathrm{yr}$, while the public should not be exposed to more than an average of $1 \mathrm{mSv} / \mathrm{yr}$ (IAEA 2004; UNSCEAR 2008; ICRP, 2013). Consequently, the result shows that the exposure rates for all the locations are more than the standard background radiation of $1 \mathrm{mSv} / \mathrm{yr}$ by almost $50 \%$. The mean background radiation profile of the entire surveyed area compared with standard is shown Figure 2 . Nonetheless, the result also shows that radiation levels in the study area are below the global average of 2.4 $\mathrm{mSv} / \mathrm{yr}$ for the general public (WHO, 2011) but far below the safe radiation limit of $20 \mathrm{mSv} / \mathrm{yr}$ for occupational environment (UNSCEAR, 2008).

Table 1: Location of Measurement Points around Asa-Dam Area, Illorin, Nigeria

\begin{tabular}{|c|c|c|}
\hline \multicolumn{2}{|c|}{ Stations } & GPS \\
\hline 1 & $\mathrm{~N}^{\prime} 8^{\circ} 26.809^{\prime}$ & $\mathrm{E}^{2} 04^{\circ} 34.352^{\prime}$ \\
\hline 2 & N08 $26.828^{\prime}$ & $\mathrm{E}^{2} 04^{\circ} 34.464^{\prime}$ \\
\hline 3 & $\mathrm{~N} 08^{\circ} 26.815^{\prime}$ & $\mathrm{E} 004^{\circ} 34.442^{\prime}$ \\
\hline 4 & N08 ${ }^{\circ} 26.805^{\prime}$ & $\mathrm{E} 004^{\circ} 34.369^{\prime}$ \\
\hline 5 & N08 $26.784^{\prime}$ & $\mathrm{E} 004^{\circ} 34.367^{\prime}$ \\
\hline 6 & N08 $26.767^{\prime}$ & $\mathrm{E}^{2} 04^{\circ} 34.342^{\prime}$ \\
\hline 7 & N08⒉ 27.192' & $\mathrm{E} 004^{\circ} 33.380^{\prime}$ \\
\hline 8 & N08⒉ $27.188^{\prime}$ & $\mathrm{E} 004^{\circ} 33.336^{\prime}$ \\
\hline 9 & N08⒉ $27.188^{\prime}$ & $\mathrm{E} 004^{\circ} 33.336^{\prime}$ \\
\hline 10 & N08을.958' & $\mathrm{E} 004^{\circ} 32.671^{\prime}$ \\
\hline 11 & N08 $26.953^{\prime}$ & $\mathrm{E} 004^{\circ} 32.652^{\prime}$ \\
\hline 12 & N08 ${ }^{\circ} 26.970^{\prime}$ & $\mathrm{E} 044^{\circ} 32.539^{\prime}$ \\
\hline 13 & N08ํ⒉964' & $\mathrm{E} 004^{\circ} 32.525^{\prime}$ \\
\hline 14 & N08 $26.950^{\prime}$ & $\mathrm{E} 004^{\circ} 32.577^{\prime}$ \\
\hline 15 & N08 $27.028^{\prime}$ & $\mathrm{E} 004^{\circ} 32.458^{\prime}$ \\
\hline 16 & N08 $27.047^{\prime}$ & E044 $32.391^{\prime}$ \\
\hline 17 & N08 $27.156^{\prime}$ & $\mathrm{E} 004^{\circ} 32.223^{\prime}$ \\
\hline 18 & N08 $27.141^{\prime}$ & E044 $32.242^{\prime}$ \\
\hline
\end{tabular}


Table 2: lonizing Radiation Measurements around Asa-Dam Area, Illorin, Nigeria

\begin{tabular}{ccccc}
\hline Stations & $\begin{array}{c}\text { Monitor } \\
1(\mathrm{mSv} / \mathrm{yr})\end{array}$ & $\begin{array}{c}\text { Monitor } \\
2(\mathrm{mSv} / \mathrm{yr})\end{array}$ & $\begin{array}{c}\text { Monitor } \\
3(\mathrm{mSv} / \mathrm{yr})\end{array}$ & Average $(\mathrm{mSv} / \mathrm{yr})$ \\
\hline 1 & 1.62 & 1.67 & 1.78 & $1.69 \pm 0.08$ \\
2 & 1.63 & 1.58 & 1.67 & $1.63 \pm 0.04$ \\
3 & 1.67 & 1.57 & 1.63 & $1.62 \pm 0.05$ \\
4 & 1.68 & 1.66 & 1.75 & $1.70 \pm 0.04$ \\
5 & 1.53 & 1.51 & 1.52 & $1.52 \pm 0.01$ \\
6 & 1.71 & 1.70 & 1.74 & $1.72 \pm 0.02$ \\
7 & 1.71 & 1.69 & 1.75 & $1.72 \pm 0.03$ \\
8 & 1.42 & 1.37 & 1.44 & $1.41 \pm 0.04$ \\
9 & 1.42 & 1.39 & 1.47 & $1.43 \pm 0.05$ \\
10 & 1.44 & 1.45 & 1.50 & $1.46 \pm 0.09$ \\
11 & 1.41 & 1.44 & 1.49 & $1.45 \pm 0.04$ \\
12 & 1.07 & 1.10 & 1.15 & $1.11 \pm 0.05$ \\
13 & 1.50 & 1.53 & 1.58 & $1.54 \pm 0.04$ \\
14 & 1.47 & 1.50 & 1.55 & $1.51 \pm 0.04$ \\
15 & 1.43 & 1.38 & 1.35 & $1.39 \pm 0.13$ \\
16 & 1.22 & 1.19 & 1.14 & $1.18 \pm 0.01$ \\
17 & 1.28 & 1.24 & 1.18 & $1.23 \pm 0.05$ \\
18 & 1.50 & 1.49 & 1.43 & $1.47 \pm 0.04$ \\
\hline Mean & $1.43 \pm 0.17$ & $1.47 \pm 0.17$ & $1.51 \pm 0.20$ & $1.49 \pm 0.04$ \\
Range & $1.07-1.71$ & $1.10-1.70$ & $1.14-78$ & $1.11-1.72$ \\
\hline
\end{tabular}

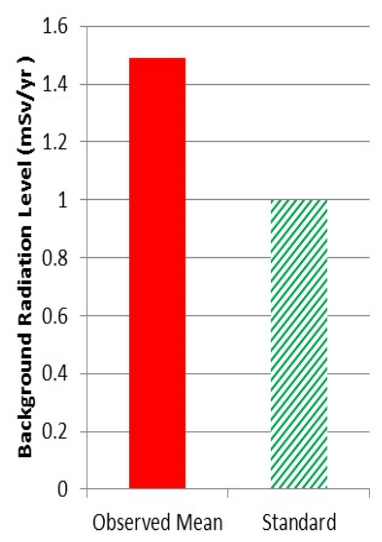

Figure 2: Radiation profile of the entire surveyed area compared with standard

According to the International Commission on Radiological Protection (ICRP), dose limits are intended to serve as a boundary condition that will prevent deterministic effects and limit the probability of stochastic effects. Stochastic effects are cancer inducing or heritable effects involving the development of cancer and may occur in either mature somatic cells or through the mutation of germ (reproductive) cells, while deterministic effects which are often of an acute nature, are mostly the result of death or malformation of somatic cells following radiation exposure, and only appear if the radiation dose exceeds a threshold value (Strom, 2003). Consequently, the limits for occupational workers are $20 \mathrm{mSv}$ (2,000 mrem) per year, averaged over defined periods of five years, with the further provision that the dose should not exceed $50 \mathrm{mSv}(5,000 \mathrm{mrem})$ in any single year. The ICRP and other related organizations also estimate that dosesrising above $1 \mathrm{mSv}$ (100 mrem) per year will justify the introduction of protection actions for members of the general public (IAEA 2004; UNSCEAR 2008; ICRP, 2013). More so, the total worldwide 
average dose from natural radiation is approximately $2.4 \mathrm{mSv} / \mathrm{yr}$, which varies between 1 and $10 \mathrm{mSv} / \mathrm{yr}$ depending on the geology and altitude where people live. However, it is reported that there is no evidence of increased cancers or other health problems arising from these average global natural levels (WNA, 2014). As stated above, the general population in the present study area is annually exposed to a background radiation of $1.49 \pm 0.04 \mathrm{mSv}$. Therefore, the implication is that the baseline risk of cancer occurrence in the study area could result from carcinogens other than radiation or a stochastic process for both occupational workers and the general public. Despite these findings, the ICRP further endorses the general philosophy of not only keeping exposures below the dose limits but also maintaining all exposure levels "as low as reasonable achievable"

\section{CONCLUSION}

This study is intended to reveal the levels of external background radiation around quarry sites in llorin industrial area of north-central Nigeria where very little published data exists on such topics. Notwithstanding that the radiation levels are below the global average for the general public and the safe radiation limit as recommended for non-nuclear work environment, the levels recorded are higher than the standard background radiation level. The areas with readings above $1.5 \mathrm{mSv} / \mathrm{yr}$ should be monitored closely. It is also necessary to recommend that domestic housing facilities be situated far away from the quarry sites and other adequate measures taken to protect the general public from adverse radiation health effect. More so, continuous monitoring and assessment of ionizing radiation in the area is suggested.

\section{REFERENCES}

Adekunle, A.S. and Eniola, I.T.K. (2008). Impact of Industrial Effluents on Quality of Segment of Asa River within an Industrial Estate in Ilorin, Nigeria. New York Science Journal, 1(1): 17 - 21.

Avwiri, G.O., Enyinna, P.I. and Agbalagba, E.O. (2007). Terrestrial radiation around oil and gas facilities in Ughelli, Nigeria. Journal of Applied Sciences, 7: 1543-1546.

Avwiri, G.O., Chad-Umoren, Y.E., Enyinna, P.I. and Agbalagba, E.O. (2009). Occupational radiation profile of oil and gas facilities during production and off- production periods in Ughelli, Nigeria. FACTA UNIVERSITATIS: Working and Living Environmental Protection, 6(1): 11 - 19.
Federal Environmental Protection Agency (FEPA) (1991). Guideline and Standard for Environmental Pollution Control in Nigeria. Lagos, Nigeria.

Gbadebo, A. M., Ayedun, H. and Okedeyi, A. S. (2011). Assessment of radiation Level within and around Stonebridge Quarry site, km 22 Lagos Ibadan Express Way, Southwest Nigeria. Environmental Research Journal, 5 (2): 25-30.

International Atomic Energy Agency (IAEA) (2004). Radiation, People and the Environment. Report No. IAEA/PI/A.75/04-00391, Austria.

International Commission on Radiological Protection (ICRP) (2013). Publication 121: Radiological Protection in Paediatric Diagnostic and Interventional Radiology, Annals of the ICRP, 42 (2), $1-63$.

Kurnaz, A., Kucukomeroglu, B., Damla, N. and Cevik, U. (2011). Radiological maps for Trabzon, Turkey. Journal of Environmental Radioactivity, 10: 393-399

World Nuclear Association (WNA) (2014). Nuclear Radiationand Health Effects. Assessed on 30 July 2014 from http://www.world-nuclear.org/info/ Safety-and-Security/Radiation-and-ealth/NuclearRadiation-and-Health-Effects.

Nwankwo, L.I. and Akoshile, C.O. (2005). Monitoring of external background radiation level in Asa Dam industrial area of Ilorin, Kwara State, Nigeria. Journal of Applied Sciences and Environmental Management, 9(3): 75 - 78.

Strom, D.J. (2003). Health Impacts from Acute Radiation Exposure. U.S. Department of Energy. DE-AC06-76RLO 1830.

Suflita, J.M., Robinson, J.M. and Tiedje, J.M. (1983). Kinetics of microbial dehalogenation of haloaromatic substrates in methanogenic environment. Applied and Environmental Microbiology, 45(5): 1466 - 1473.

Thomas, J.M., Ward, C.H., Raymond, R.L., Wilson, J.T. and Lohehr, R.C. (1992). Bioremediation. In Encyclopedia of Microbiology I (J. Lederberg ed.) Academic Press London. 369 - 377.

United Nations Scientific Committee on the Effects of Atomic Radiation (UNSCEAR) (2008). Sources and Effects of lonizing Radiation. Report to the General Assembly with Scientific Annexes. Vol. 1. New York.

World Health Organization (WHO) (2011). Guidelines for drinking-water quality: Radiological Aspects. Geneva 